\title{
ORGANIZATION AND MANAGEMENT OF TOURIST ATTRACTIONS. CASE STUDIES OF LOWER SILESIA PROJECTS
}

\section{KAZIMIERZ KLEMENTOWSKI, ${ }^{1}$ MARIUSZ SOŁTYSIK, ${ }^{2}$ ZYGMUNT SAWICKI, $^{3}$ SOÑA JANDOVÁ, ${ }^{4}$ PIOTR OLEŚNIEWICZ ${ }^{5}$}

\footnotetext{
${ }^{1}$ University of Business in Wrocław, Poland

e-mail: kazimierz.klementowski@handlowa.eu

${ }^{2}$ University School of Physical Education in Wrocław, Poland

e-mail: mariusz.soltysik@awf.wroc.pl

${ }^{3}$ University of Business in Wrocław, Poland

e-mail: zygmunt.sawicki@handlowa.eu

${ }^{4}$ Technical University of Liberec, The Czech Republic

e-mail: sona.jandova@tul.cz

${ }^{5}$ University School of Physical Education in Wrocław, Poland

e-mail: piotr.olesniewicz@awf.wroc.pl
}

\begin{abstract}
\begin{tabular}{l|l} 
JEL CODES & R11, R58, Z32
\end{tabular}
KEYWORDS tourist attractions, sightseeing values, organization and management, Lower Silesia

ABSTRACT Tourist attractions are changing dynamically in terms of form, location, scale, and manner of their creation. This thesis is confirmed by the selected tourist attractions of Lower Silesia presented in the paper. They are an important phenomenon for tourism, as they play a special role in creating the regional tourist product. However, the function of tourist attractions in this area is changing. The expectations of tourist traffic participants and tour operators evolve, which results in changes in the market of tourist attractions, considered a complex and efficiently managed tourist product.
\end{abstract}

\section{Introduction}

Tourist attractions are an important component of the tourist market. They stimulate interest in visiting a tourist destination and guarantee visitors' satisfaction. They invite tourists to the region and stimulate demand for other tourist services (Gunn, Rusk, 1979), playing a special role in creating tourist products. 
The role of tourist attractions in the tourist activity and contemporary economy is changing. Consumer demands and the innovation of tour operators have led to an evolution and diversification of the sector. Tourist attractions are changing dynamically in form, location, scale, and style.

Selected tourist attractions of Lower Silesia created within the recent 25 years are the subject of analysis in the paper. The criterion for their choice was the high level of interest in the offered tourist product.

\section{Tourist attractions: theoretical approach and curpent state of research}

So far, the term 'tourist attractions' has been rarely used in the Polish literature of tourism economy, and thus has not been clearly defined. Terms similar in meaning are commonly used, such as 'tourist values' or 'sightseeing values' (Rogalewski, 1972). In the English language literature, the notion of 'tourist value' is infrequent; the synonymous 'tourist attractions' are rather referred to. In its broad sense, a tourist attraction denotes a place which attracts tourists' attention because of its specific characteristics. Literature also provides related terms, such as German 'touristische Attraktionen' and French 'attractions touristiques'.

The notion of tourist attractions was introduced by E. Cohen (1972), who stated that visiting tourist attractions was the main purpose of mass foreign tourism. He divided the attractions into the real ones, appealing because of their specific features, and artificial ones, 'invented' for tourists. According to Cohen, a feature of mass tourism is 'adding attractiveness' to tourist attractions. He claimed that even 'natural' attractions were made more attractive for the sake of tourism consumption. Since then, numerous definitions of tourist attractions have been developed. Among the earliest ones is that by D. Lundberg (1985), referring to attractions as anything that interests tourists: tourist attractions include all the elements that make tourists leave their homes. A. Lew (1987) depicts tourist attractions in a similar way.

For B. Goodall (1990), tourist attractions are particular places, often unique, such as the natural environment or a monument of history. Z. Sawicki mentions artistic events (2016) and spots events (2013). K. Podemski (2004) perceives tourist attractions in a broader way, including price levels, local population attitudes towards tourists and tourism, tourist facilities, and infrastructure.

Contemporarily, the systemic definition by D. MacCannell (2002) contributes much to the discourse: a tourist attraction is an empirical relation of the tourist, the sight, and the marker (information on the place).

The term 'tourist attractions' is difficult to define. The existing definitions differ in terms of objectives, disciplinary approach, and applicability. J. Swarbrooke (1995) divides attractions into four groups:

- natural tourist attractions,

- works created by man for a purpose other than attracting tourists, which over time have become attractions,

- places designed from scratch as attractions,

- cultural, sports, and religious events, festivals, Olympic Games, etc. 
Another classification suggested by J. Swarbrooke (1995) is the following:

- basic attractions (the main reason for traveling and the main place of spending time),

- secondary attractions (the ones 'on the way').

With this understanding of tourist attractions, the tourist values should be seen as a more general, objective category, encompassing the characteristics which provide a potential basis for tourist phenomena development. Tourist attractions, in turn, seem to be a subjective category, as they require appropriate organization and promotion. Tourist attractions can be created anew, even in areas primarily devoid of tourist values.

In tourist economy, tourist attractions are treated as a specific tourist product. It is generally recognized in the literature that a tourist product is a complex set of tangible and intangible characteristics including usefulness and functional, social, and psychological benefits. Its market value is also considered. These features form the core of the product or its essence, the core being the main advantage that the tourist wants to take. S. Bosiacki and J. Sikora (1999) point out that the basic product, i.e. tourist attractions in their essence, contains basic values meeting specific tourist needs and constitutes the basic version of the choice.

What is important in this respect are the properties and attractiveness of the product, i.e. of the tourist attraction. The concepts of 'expected product' and 'extended/enriched product' are also bound with this issue. The expected product is a set of additional features that the customer expects when buying the basic product (e.g. uniqueness, quality, price). In turn, an extended/enriched product is a product offered ahead of expectations. It contains additional benefits that make the offer distinctive. All these elements constitute the potential product, of possible interest to the customer. Moreover, the tourist attraction as a product includes the capacity of further development, encouraging tourists to visit the site again and to pass on positive opinions.

It is worth to recall the opinion of Z. Kruczek $(2002,2005)$ pointing out that many attractions are accompanied by tourist traps, designed to draw money from tourists. The author states that although such products meet the definition of tourist attractions, the extremely extensive commercial setting is inadequate for the quality of the product core.

Tourist attractions are the subject of interest of social, economic, natural, and spatial sciences. In Poland, tourist attraction research have been performed mainly by M. Nowacki (2000a, 2000b, 2002, 2003), and also by Z. Kruczek (2002), K. Podemski (2004), K. Kożuchowski (2005), and the Institute of Tourism (Byszewska-Dawidek, Kulesza, 2004).

\section{Genesis, management, and structure of the tourist product of selected tourist attractions in Lower Silesia}

The analysis involved the Museum of Industry and Railway in Silesia in Jaworzyna Sląska, Museum of Gold Mining and Metallurgy in Złoty Stok, and Arboretum in Wojsławice. The aim was to answer the following questions:

- What was the genesis and the organizational process of the facilities?

- What kind of entities participated in the creation of the projects and who financed them? 
- What is the structure of the offered tourist products and how does it influence tourism interest?

- Have the analysed undertakings contributed to local socio-economic activation, and to what extent?

\section{Museum of Industry and Railway in Silesia in Jaworzyna Śląska}

The museum operates on the premises of the former Polish State Railways locomotive facility. In 2004, the Museum of Steam Locomotives created there was handed over to the municipality of Jaworzyna Śląska.

The Museum of Industry and Railway in Silesia is now a social institution, supervised by the Ministry of Culture, with the status of a public benefit organization. It is financed by the Founder and the statutory activity. The main objective of the museum is to protect the technical heritage in Silesia and to implement didactic and scientific activities. Since January 2017, the museum has been a part of the Foundation for the Protection of Silesian Industrial Heritage, a non-government organization.

The exposition is the basic element and core of the potential tourist product and contains the values meeting the cognitive and educational needs of tourists, constituting the basis for choosing the museum as a tourist destination. The expected tourist product is historic railway machinery and equipment, as well as an exhibition of historic motorcycles or radio receivers. The extended/ enriched product includes trips and festivals. Taking into account the specificity of the exhibition, the tourist product turns out extremely popular, as in years 2014-2017 it was attended by 55-65 thousand people per year.

In the early 1990s, Jaworzyna Śląska had hardy any significance in the tourist structure of Lower Silesia. It was the unique Museum of Industry and Railway in Silesia that contributed to perceiving Jaworzyna Śląska as a place of tourist attractiveness. The increasing tourist traffic and the consequent demand for tourist services resulted, among others, in developing three hotels and four catering facilities.

\section{Museum of Gold Mining and Metallurgy in Zloty Stok}

It is located in the former gold mine in Złoty Stok, dating back to the $13^{\text {th }}$ century. In 1962 , mining and metallurgy were definitively discontinued here and the mine was sunk within a short time as a result of natural water circulation.

In the early $1990 \mathrm{~s}$, the decision was taken to make the abandoned and flooded mine available for tourism. In 1996, the underground tourist route was launched. Year 2001 was a breakthrough for the facility, as Elżbieta Szumska became the majority shareholder of the management company. She initiated an ambitious program to expand the exhibition and the range of tourist services. The Golden Mine is now a unique attraction on a European scale. The museum is visited by about 250 thousand people every year. 
Still in the 1990s, Złoty Stok, a town situated on an important tourist route, did not stand out in the tourist structure of Lower Silesia. Currently it is an important tourist destination. The particular success of the project was determined by the quality and complex structure of the tourist product.

The underground tourist route and the exposition are the basic elements and core of the potential tourist product, constituting the basis for choosing the museum as a tourist destination. The expected tourist product is the Forest Adventure Park, the Paintball City, the Medieval Technology Park, and the Labyrinth of Fear. The extended/enriched product includes hotel and catering facilities.

The project joins a museum function and a commercial function. This is reflected in the range of the supplementary offer. The museum also plays an important city-forming role, providing employment to about 300 inhabitants.

\section{Arhoretum in Wojsławice}

The natural values of the Niemcza-Strzelin Hills created favourable conditions to establish a romantic garden in Wojsławice in the mid- $19^{\text {th }}$ century. However, the wasteful exploitation resulted in a gradual devastation of the facility.

In 1977, the Commission of Botanical Gardens and Arboreta in Poland gave the Wojsławice park the arboretum status, and in 1983, the facility (almost 5 ha) was entered into the register of monuments of culture. Since 1988, the Arboretum, now with the area of 62 ha, has been a branch of the Botanical Garden of the University of Wrocław. The University has obtained significant resources from the Lower Silesia Regional Operational Program and from the European Union targeted funds. In the late 1990s, intensive works were undertaken to adapt the natural environment of the Arboretum to the tourist traffic needs and to create a modern tourist product on its basis.

The commercial success of the Arboretum is mainly conditioned by its structure, tourist product quality, and favourable location. The basic elements and core of the potential tourist product are the historic part, the National Collection of Rhododendrons of the Lusatian Race, boxes, and the biggest European collection of daylilies. The numerous exhibitions, competitions, and concerts constitute the expected product, and the considerably developed infrastructure creates the extended/enriched product.

Over the last five years, the Arboretum has been visited by approximately 70 thousand domestic and foreign tourists per year. It is gradually becoming an important factor in the social and economic activation of the nearby Niemcza.

The rich tourist potential of Niemcza has been adequately appreciated in the plans and programs of tourist spatial development of the whole country and Lower Silesia. However, the progressing degradation of the town, and the deteriorating aesthetics and technical condition of historic buildings result in a low tourist interest. 


\section{Conclusions}

Attractions play a specific role in creating tourist product. This role, though, is undergoing constant changes. The expectations of tourist traffic participants and tour operators evolve, modifying the tourist attractions market.

Tourist attractions change dynamically in their form, location, scale, and way of creation. This is depicted in the three presented tourist attractions of Lower Silesia. Two of them, the Museum of Industry and Railway in Silesia and the Museum of Gold Mining and Metallurgy, promote postindustrial values of the Lower Silesian cultural heritage. The Arboretum joins scientific, didactic, and commercial aims.

At the beginning, the process of creating these projects was similar, with a significant importance of social and public factors, whose activity stimulated local self-governments to develop the centres of tourist reception. Then, however, it turned out that maintaining or supporting the facilities exceeded the capacity of the individual municipalities. As a result, each object represents a different sector of national economy:

- Museum of Industry and Railway in Silesia - social sector,

- Museum of Gold Mining and Metallurgy - private sector,

- Arboretum - public sector.

An important factor determining the attractiveness of the objects is the complex construction of their tourist product. The basic cognitive values are accompanied by an extensive infrastructure offer.

The performed analyses did not reveal differences in the effectiveness of the facilities' organization or management with regard to their ownership. In all cases, the activity aims at increasing the project popularity and recognition on the market. The indicated attractions (products) constitute an area characteristic, already being a target or an environment of tourist migrations of at least regional significance, and their development lets assume that their range of interest will increase to the national level.

In terms of the impact of the described products on the socio-economic environment and the tourist traffic, it should be assumed that it will gradually increase, although their development so far is considered extensive rather than intensive. One can also believe that all indicators of the condition and development dynamics of the presented tourist attractions will contribute to revitalisation and socio-economic and tourist activation of the areas.

It should be stressed at this point that the directions of transformations and management of the discussed attractions adopted by the local governments turned out particularly relevant and despite many organizational and economic limitations led not only to their maintenance, but also to their successive development and stabilization in the Lower Silesia tourist market.

\section{References}

Bosiacki, S., Sikora, J. (1999). Podstawy marketingu w turystyce i rekreacji. Poznań: AWF.

Byszewska-Dawidek, M., Kulesza, I. (2004). Krajowy rynek atrakcji turystycznych. Warszawa: Instytut Turystyki. 
Cohen, E. (1972). Towards a sociology of international tourism. Social Research, 39, 164-182.

Goodall, B. (1990). The dynamics of tourism place marketing. In: G. Ashworth, B. Goodall (eds.), Marketing Tourism Places (pp. 259-279). London: Routledge.

Gunn, S., Rusk, C.A. (1979). Tourism planning. New York: Crane, Russak and O.

Kożuchowski, K. (2005). Walory przyrodnicze w turystyce i rekreacji. Poznań: Wydawnictwo Kurpisz.

Kruczek, Z. (2002). Atrakcje turystyczne. Metody oceny ich odbioru - interpretacja. Folia Turistica, 13, 37-61.

Kruczek, Z. (2005). Polska. Geografia atrakcji turystycznych. Kraków: Proksenia.

Lew, A. (1987). A framework of tourist attraction research. Annals of Tourism Research, 14 (4), 533-575.

Lundberg, D. (1985). The tourist business. New York: Van Nostrand Reinhold.

MacCannell, D. (2002). Turysta. Nowa teoria klasy próżniaczej. Warszawa: Muza SA.

Nowacki, M. (2000a). Analiza potencjału atrakcji krajoznawczych na przykładzie Muzeum Narodowego w Szreniawie. Problemy Turystyki, 23 (1-2), 45-60.

Nowacki, M. (2000b). Rola interpretacji dziedzictwa w zarządzaniu atrakcjami turystycznymi. Problemy Turystyki, 23 (3-4), 35-47.

Nowacki, M. (2002). Ocena jakości produktu atrakcji turystycznej z wykorzystaniem metody Servqual. Turyzm, 12 (1), $55-73$.

Nowacki, M. (2003). Wrażenia osób zwiedzających atrakcje turystyczne. Folia Turistica, 14, 117-132.

Podemski, K. (2004). Socjologia podróży. Poznań: Wydawnictwo Naukowe UAM.

Rogalewski, O. (1972). Podstawy gospodarki przestrzennej w turystyce. Ruch turystyczny - monografie. Warszawa: SGPiS.

Sawicki, Z. (2013). Four Hills Tournament in Oberstdorf as a main tourism product of the Alps region. In: J. Marak, J. Wyrzykowski (eds.), Tourism role in the regional economy, vol. 4, Regional tourism product-theory and practice (pp. 591-600). Wrocław: University of Business in Wrocław.

Sawicki, Z. (2016). The Bayreuth Festival of Richard Wagner as a main product of cultural tourism in Bavaria. In: J. Marak, J. Wyrzykowski, S. Toczek-Werner (eds.), Tourism role in the regional economy, vol. 6, Cultural tourism as a branded tourism product of cities, towns and regions (pp. 192-200). Wrocław: University of Business in Wrocław.

Swarbrooke, J. (1995). The development and management of visitors attractions. Oxford: Butterworth-Heinemann.

\section{ORGANIZACJA I ZARZĄDZANIE ATRAKCJAMI TURYSTYCZNYMI. STUDIUM PRZYPADKÓW PRZEDSIĘWZIĘĆ DOLNOŚLĄSKICH}

SŁOWA KLUCZOWE STRESZCZENIE atrakcje turystyczne, walory krajoznawcze, organizacja i zarządzanie, Dolny Śląsk

Atrakcje turystyczne zmieniają się dynamicznie w zakresie formy, lokalizacji, skali i sposobu kreacji. Potwierdzeniem tej tezy są zaprezentowane w pracy wybrane atrakcje turystyczne Dolnego Śląska, wykreowane w okresie ostatnich 25 lat. Są one zjawiskiem ważnym dla turystyki, gdyż pełnią szczególną funkcję w tworzeniu regionalnego produktu turystycznego. Jednak rola atrakcji turystycznych w tym zakresie się zmienia. Oczekiwania uczestników ruchu turystycznego i organizatorów turystyki podlegają ewolucji, co skutkuje zmianami na rynku atrakcji turystycznych, traktowanych przez nich w kategorii złożonego w swojej konstrukcji i efektywnie zarządzanego produktu turystycznego. 